ANNA PASZKOWSKA-ROGACZ ID orcid.org/0000-0002-9426-4888

Instytut Psychologii, Uniwersytet Łódzki Institute of Psychology, University of Lodz e-mail: anna.paszkowska-rogacz@uni.lodz.pl

\title{
Perspektywa temporalna młodych dorosłych a ich zadowolenie z życia. Moderujący efekt poczucia dorosłości
}

\section{Time Perspective and Satisfaction of Life of Young Adults. Moderation Effect of the Sense of Adulthood}

\begin{abstract}
The study sought to investigate the relationship between time perspectives (TP) and the life satisfaction (LS) of young adults with the moderation effect of two dimensions of the sense of adulthood as a task and as a limitation The study involved 208 people aged 19-35 years $(\mathrm{M}=23,45 ; \mathrm{SD}=3,17)$ who filled out the Sense of Adulthood Scale of Zagórska, The Satisfaction with Life Scale of Juczyński, and the Zimbardo Time Perspective Inventory. As predicted, the effect of moderation was obtained in three models, where the dependent variable was life satisfaction - in the case of a negative past perspective and deviation from the balanced time perspective and adulthood perceived as a limitation, as well as in relation to the past positive perspective and adulthood perceived as a task.
\end{abstract}

Keywords: sense of adulthood, time perspective, life satisfaction

Słowa kluczowe: poczucie dorosłości, perspektywa temporalna, satysfakcja z życia

\section{WPROWADZENIE}

Wśród zmian gospodarczych, demograficznych i społecznych, obserwowanych w ostatnich dekadach w większości społeczeństw zachodnich, zachodzą również te związane z procesem wchodzenia w dorosłe życie. Obserwuje się coraz późniejsze kończenie edukacji, opuszczanie domu rodzinnego oraz prowadzenie samodzielnego gospodarstwa domowego, zawieranie związku małżeńskiego czy urodzenie dziecka, czyli osiąganie tzw. markerów dorosłości (Arnett, 2000; Brzezińska, 2000; Murphy, Blustein, Bohlig, Platt, 2010; Settersten, 2011), co być może jest związane z koniecznością funkcjonowania $\mathrm{w}$ ciagle modyfikowanych warunkach rynku pracy oraz radzenia sobie z charakterystyczną dla niego globalizacją, nieciągłością i niepewnością (Bańka, 2007). $\mathrm{Z}$ analiz demograficznych zaprezentowanych przez zespół Głównego Urzędu Statystycznego (Cierniak-Piotrowska i in., 2019) wynika, że konsekwencją wyborów dokonywanych przez młodych ludzi, którzy planując przyszłość, rodzinę stawiają na dalszym miejscu, jest zwiększenie się wieku nowożeńców. W 2018 roku mediana wieku mężczyzny zawierającego małżeństwo wyniosła 30 lat, a kobiety prawie 28 lat - w przypadku obydwu płci jest to o ponad cztery lata więcej niż w 2000 roku (pojawia się też większa liczba związków nieformalnych). Co więcej, po 1990 roku nastąpiło podwyższenie mediany wieku kobiet rodzących dziecko, która w 2018 r. wyniosła 30 lat wobec około 26 lat w latach 1990-2000. W tym okresie zwiększył się także - o prawie 
pięć lat - średni wiek urodzenia pierwszego dziecka - w 2017 roku wyniósł prawie 28 lat.

Z obserwacji zmieniającej się rzeczywistości zrodziła się potrzeba wyszczególnienia i opisania etapów rozwojowych, będących łącznikiem pomiędzy okresem dojrzewania i dorosłości. Poprzez eksperymentowanie i aktywne poszukiwanie nowych doświadczeń, jednostka buduje swoją tożsamości w takich obszarach życia, jak miłość, kariera czy światopogląd (Bańka, 2007). Tendencję tę potwierdzają ogólnopolskie badania młodych Polaków w wieku 18-29 lat (Wiszejko-Wierzbicka, Kwiatkowska, 2018), które z jednej strony wykazały istnienie zindywidualizowanych planów wchodzenia w dorosłość, w których kolejne obowiązki są wyznaczane nie przez narzucone z zewnątrz zadania dorosłości, lecz przez wewnętrzny barometr poczucia gotowości do ich podjęcia, a z drugiej strony ujawniły, że spory odsetek osób badanych odrzuca dorosłość, nie chce zaakceptować jej ciężaru, tęskni za dzieciństwem i chce korzystać z uroków życia w pojedynkę (Oleszkowicz, Misztela, 2015). Według Małgorzaty Rękosiewicz (2014), oprócz obiektywnych markerów wejścia w dorosłość, takich jak narodziny dziecka lub uzyskanie stałej pracy, należy brać pod uwagę również wyznaczniki subiektywne. Autorka wymienia wśród nich poczucie dorosłości oraz uzyskanie przewagi orientacji tranzytywnej (związanej z realizacją kolejnych, dorosłych zadań rozwojowych) nad moratoryjną (związaną z koncentracją na teraźniejszości i korzystaniem z bieżących możliwości). Podobny pogląd prezentuje Wanda Zagórska (2004), która gotowość do podjęcia zadań charakterystycznych dla tego okresu życia oraz posiadanie obrazu własnego w nim funkcjonowania wiąże również z poczuciem dorosłości. Procesy te zawierają się w pojęciu wczesnej dorosłości (Gurba, 2011) i polegają na uniezależnianiu się od rodziców, kształtowaniu swojej tożsamości, nawiązywaniu intymnych relacji, podejmowaniu odpowiedzialności za swoje decyzje i działania, która pozwala na samodzielność w formułowaniu celów. Opisane w dalszej części artykułu wyniki badań weryfikują siłę oddziaływania poczucia dorosłości na względnie stałą dyspozycję osobo- wościowa, jaką jest perspektywa temporalna w kontekście związku tej perspektywy z zadowoleniem z życia.

\section{PERSPEKTYWA TEMPORALNA I ORIENTACJA CZASOWA A ZADOWOLENIE Z ŻYCIA}

Pojęciem, które wydaje się kluczowe w sytuacji planowania i podejmowania przez młodych ludzi decyzji dotyczących teraźniejszości i przyszłości jest perspektywa temporalna. Jej rozwój jest procesem związanym ze wzrostem umiejętności poznawczych, które umożliwiają tworzenie powiązań między wydarzeniami w różnych wymiarach czasowych (Molinari i in., 2016). Czas jest nieodłączną częścią ludzkiej egzystencji, a - jak piszą Thomas Suddendorf i Michael C. Corballis (1997) - zdolność mentalnej podróży w przeszłość i przyszłość jest atrybutem charakterystycznym dla człowieka jako gatunku. Wielu badaczy dostrzega, że czas należy definiować także z perspektywy psychologicznej - czyli tej odczuwanej subiektywnie przez każdą jednostkę (Fraisse, 1963; Łukaszewski, 1984; Tucholska, 2007). Z kolei definicja psychologiczna orientacji temporalnej zawiera zarówno perspektywę temporalną, jak i organizację działania w czasie (Block, 1990; Hoonaert, 1973; Ornstein, 1969, Nawrat, 1981; Nuttin, 1985); stąd, według Czesława Nosala i Barbary Bajcar (2004), orientacja czasowa nie tylko wyraża osobiste zaangażowanie i koncentrację uwagi jednostki na przeszłości, teraźniejszości lub przyszłości, ale także wskazuje na rozpiętość i zorganizowanie aktywności podmiotu. Każdy z tych przedziałów czasu dotyczy odmiennych struktur poznawczych oraz prowadzi do różnych konsekwencji w zachowaniu człowieka (Chlewiński, 1977; de Volder, Lens, 1982; Łukaszewski, 1983; Nuttin, 1985; Obuchowski, 1987; Pawluczuk, 1987; Zaleski, 1991). Oba pojęcia - perspektywa temporalna i orientacja czasowa - bywają niejednokrotnie w literaturze przedmiotu utożsamiane i używane zamiennie. Jest to charakterystyczne dla takich autorów jak Zbigniew Zaleski (1988) czy Ryszard Nawrat (1981). W niniejszym opraco- 
waniu konsekwentnie stosowane będzie jednak pojęcie perspektywy temporalnej (za: Zimbardo i Boyd, 2009) $)^{1}$.

Wielu badaczy reprezentujących rozwojowe podejście life-span wiąże wiek psychologiczny, dotyczący perspektywy temporalnej, z wiekiem życia człowieka (Alwin i in., 2011; Carstensen, 2006; Carstensen i in., 1999). Stwierdzono na przykład, że zarówno wśród młodszej, jak i starszej generacji przeważa perspektywa teraźniejsza i przyszła, ale to osoby młodsze myślą o przyszłości częściej niż osoby starsze, z kolei ta druga grupa obawia się przyszłości i przeżywa lęk przed nadchodzącym schyłkiem życia (Desmyter, De Raedt, 2012; Fingerman, Perlmutter, 1995; Holman, Silver, 2005). Również analiza porównawcza perspektyw temporalnych w badaniach podłużnych, prowadzonych przez Hannę Liberską (2004), wskazała na tendencję spadkową wskaźników perspektywy przyszłej wraz z wiekiem badanych. Z kolei badania podłużne dotyczące zmian związku perspektyw temporalnych ze stresem wraz z upływem czasu wykazały spadek negatywnej perspektywy przeszłej oraz wzrost perspektywy przyszłej (Holman, Silver, Mogle, Scott, 2016). Co więcej, stres pozostawał w związku z perspektywą przeszłą tylko w grupie młodszych dorosłych (poniżej 30. roku życia). Ten ostatni wniosek znajduje uzasadnienie w badaniach sugerujących, iż starsze osoby przywiązują mniejszą wagę do bodźców stymulujących negatywne emocje (Isaacowitz, Wadlinger, Goren, Wilson, 2006). Występują jednak wyjątki od tej reguły, tzn. pojawiają się młodzi ludzie ,zamknięci” w swojej przeszłości lub osoby starsze skupione wyłącznie na przyszłości, ponieważ tworzenie się perspektywy temporalnej jest zależne od występowania następstwa zdarzeń (Fraisse, 1963; Lens, Moreas, 1994) oraz czasu ich trwania.

Alternatywny model pojmowania perspektywy temporalnej sugeruje, że należy zaliczyć ją do kategorii względnie stałych cech indywidualnych. W zależności od przedziału czasu na kontinuum temporalnym od przeszłości do przyszłości wyróżnia się osoby zorientowane na przeszłość (ang. past-oriented), na teraźniejszość (ang. present-oriented) lub na przyszłość (ang. future-oriented) (Hulbert, Lens, 1988; Lens,
2004). Jednostka należąca do pierwszej z wymienionych grup traktuje przeszłe doświadczenia jako fundament swojej perspektywy temporalnej. Perspektywa retrospektywna (przeszła) - według Philipa G. Zimbarda i jego współpracowników (Zimbardo, 2002; Zimbardo, Boyd, 1999; Zimbardo, Gonzalez, 1985) - może przyjmować dwie postaci: pozytywną i negatywną. Osoba pozytywnie zorientowana na przeszłość (ang. positive past perspective) skupia się na znaczeniu własnych korzeni, na podstawie których kształtuje poczucie własnej tożsamości i wartości. Jednostka negatywnie zorientowana na przeszłość (ang. negative past perspective) koncentruje się wyłącznie na negatywnych przeszłych doświadczeniach. Zgodnie z koncepcją P.G. Zimbarda i Johna N. Boyda (1999) w obrębie orientacji na teraźniejszość występują hedoniści (ang. present-hedonistic perspective) i fataliści (ang. present-fatalistic perspective). Ci pierwsi są spontaniczni i otwarci na nowości, swobodnie wyrażaja własne emocje. Fataliści narzekają na sytuację obecną, nie próbując jej zmienić, ponieważ są przekonani o wszechobecnym wpływie losu. Ludzie zorientowani na przyszłość (ang. $f u$ ture perspective) zajmują się planowaniem tego, czym będą się zajmować w przyszłości oraz w jaki sposób osiagną zamierzone cele. Najbardziej optymalnym sposobem funkcjonowania jest uznanie spójności przeszłości, teraźniejszości i przyszłości. Według Willego Lensa i Marie-Anne Moreas (1994) jest to przejaw ,integracji temporalnej” lub „kompetencji temporalnej". Przy takim ujmowaniu rzeczywistości przeszłość i przyszłość przejawiają się w teraźniejszości, dzięki operacyjnym mechanizmom świadomości. Podobnie P.G. Zimbardo i jego współpracownicy wprowadzili pojęcie zrównoważonej perspektywy temporalnej (ZPT; Zimbardo, Boniwell, 2007; Zimbardo, Boyd, 1999), polegającej na zdolności do płynnego i elastycznego przełączania się pomiędzy wyróżnionymi perspektywami temporalnymi w zależności od wymagań sytuacyjnych i posiadanych zasobów.

Dynamiczny rozwój badań w zakresie psychologii temporalnej dostarcza dowodów na istnienie licznych związków pomiędzy prefe- 
rowaną perspektywą czasową a innymi zmiennymi psychologicznymi. Wykazano na przykład dodatni związek perspektywy temporalnej przeszłej negatywnej z agresją, nieśmiałością, lękiem i depresja, a ujemny z poczuciem szczęścia i poczuciem własnej wartości. Odwrotne relacje zaobserwowano $w$ tych samych badaniach w odniesieniu do perspektywy przeszłej pozytywnej. Co więcej, perspektywa ta była intensywniej reprezentowana wśród kobiet. Perspektywa teraźniejsza fatalistyczna była pozytywnie związana z poszukiwaniem doznań, tendencją do kłamstwa i kradzieży, lękiem i depresją, a negatywnie ze zrozumieniem konsekwencji własnych działań i osiaggnięciami szkolnymi (Zimbardo, Boyd, 1999). Osoby z wysokimi wskaźnikami perspektywy teraźniejszej hedonistycznej okazały się twórcze, poszukujące nowości i doznań, ale też wykazywały tendencję do zachowań ryzykownych i hazardu (Hodgins, Engel, 2002). Wskazywano też negatywny związek pomiędzy teraźniejszą perspektywą czasową a osiągnięciami w nauce (Ferrari, Diaz-Moralez, 2007; Lennings i in., 1998; Simons i in., 2004). Ostatnio wiele uwagi poświęca się również analizie konsekwencji przyjmowania przez jednostki zrównoważonej perspektywy temporalnej ZPT. Cecha ta mierzona jest w różny sposób, na przykład obliczano wskaźnik ZPT, dzieląc wyniki pięciu perspektyw czasowych na niskie (poniżej 33 percentyla), umiarkowane lub wysokie (powyżej 33 percentyla). Wykorzystując tę metodę „odcięcia” stwierdzono, że osoby uzyskujące wysoki wskaźnik ZPT prezentowały znacznie wyższe poczucie szczęścia niż osoby ze wskaźnikiem niskim (Drake i in., 2008). Poza tym - dzielono badanych na grupy o zróżnicowanym wskaźniku ZPT (Boniwell i in., 2010) za pomoca hierarchicznej analizy skupień i również wykazano jego pozytywny związek z psychologicznym dobrostanem. Maciej Stolarski, Joanna Bitner i P.G. Zimbardo (2011) opracowali kolejny wskaźnik ZPT i opierając się na odchyleniu od zrównoważonej perspektywy temporalnej - OZTP określili stopień niezrównoważenia jednostek w zakresie perspektyw temporalnych. Wskaźnik ten wykorzystano w badaniach nad dobrostanem i wykazano silny pozytywny związek zrównoważonej perspektywy temporalnej z zadowoleniem z życia (Zhang i in., 2013).

W badaniach młodych osób największy jak dotychczas nacisk kładziono na perspektywę przyszłą. Być może wynikało to z przewagi takiej perspektywy wśród tej grupy, co między innymi wykazały badania Jari-Erika Nurmiego (1991) i H. Liberskiej (2004). Wyniki badań Detris H. Adelabu $(2007,2008)$, Terella P. Lasane'a i Jamesa M. Jonesa (2000) oraz Huya P. Phana (2009) wykazały, że młode osoby charakteryzujące się wyższym poziomem przyszłej perspektywy temporalnej stawiają sobie odleglejsze cele dotyczące własnej edukacji, a także mają wewnętrzne poczucie kontroli i wyższą samoocenę.

\section{PROBLEM BADAWCZY I CEL BADAŃ}

Przytoczone badania wskazują, że perspektywy temporalne okazują się istotnym predyktorem poczucia dobrostanu: perspektywa przeszła negatywna i teraźniejsza fatalistyczna pogarsza je, a przeszła pozytywna, teraźniejsza hedonistyczna i przyszła poprawia (Gao, 2011; Zimbardo, Boyd, 2009). Szczególnie w sytuacjach radzenia sobie ze stresem posttraumatycznym niekorzystna okazuje się perspektywa przeszła negatywna (Holman i in., 2016; Zimbardo i in., 2012). Wykazano również, że niektóre perspektywy temporalne mogą być bardziej (lub mniej) istotne $\mathrm{w}$ osiaganiu przez jednostkę dobrego samopoczucia (Cunningham i in., 2015; Drake $\mathrm{i}$ in., 2008; Van Beek i in., 2011; Zhang i in., 2012; Temple, 2013). Okazuje się, że z subiektywnym poczuciem dobrostanu najsilniej są powiązane perspektywa przeszła negatywna, kolejno przeszła pozytywna i teraźniejsza hedonistyczna, natomiast perspektywa teraźniejsza fatalistyczna i przyszła nie wykazują związku $\mathrm{z}$ tą zmienną.

Wśród wymienionych powyżej publikacji brakuje przykładów badań, które dotyczyłyby szczególnej grupy, jaką stanowią młodzi dorośli funkcjonujący w okresie tranzycji pomiędzy młodością i dojrzałością, pozostający w stanie swoistego „zawieszenia” pomiędzy przeszłością 
i przyszłością, a których perspektywa temporalna może ulegać zmianie. Podstawowym celem niniejszego badania jest więc analiza związków perspektyw temporalnych oraz poczucia dorosłości z satysfakcją z życia tej grupy badanych. Kolejnym celem jest próba określenia roli poczucia dorosłości, które w wyniku interakcji z perspektywami temporalnymi może modyfikować poziom zadowolenia z życia. Realizacja drugiego celu wynika z nielicznych jak dotąd badań uwzględniających moderatory związku między perspektywą czasową a satysfakcją z życia. Tao Chen i współpracownicy (2016) testowali moderujący wpływ wieku na związek między perspektywą teraźniejszą fatalistyczną a satysfakcją życiową. Autorzy oparli swoją hipotezę na teorii kontroli życia, wyróżniającej kontrolę pierwotną i kontrolę wtórną (Heckhausen, Schulz, 1995), a także na modelu strategii radzenia sobie w sposób asymilacyjny i akomodacyjny (Brandtstädter, 2009). Wiek okazał się pozytywnym moderatorem badanego związku. U młodych dorosłych oraz u osób w średnim wieku fatalistyczna perspektywa czasowa i zadowolenie z życia były istotnie ujemnie skorelowane. Nie było znaczącego związku między tą perspektywą czasową a satysfakcją z życia starszych badanych. Z kolei badania Anety Przepiórki i Małgorzaty Sobol-Kwapińskiej (2018) wykazały silny moderujący, pozytywny efekt religijności zewnętrznej (w przeciwieństwie do wewnętrznej) związku pomiędzy perspektywą przeszłą negatywną a satysfakcją z życia. Autorki sądzą między innymi, że efekt ten może wynikać z tego, iż zewnętrzna religijność (jako mniej dojrzała) może utrudniać konfrontację jednostki z rzeczywistością.

Przesłanki wynikające z przytoczonych prac dotyczących związku pomiędzy perspektywami temporalnymi i poczuciem dobrostanu oraz uwzględniających moderujący efekt wieku i dojrzałości pozwoliły na sformułowanie trzech hipotez:

Hipoteza 1: Dorosłość spostrzegana przez młodych dorosłych jako zadanie do wypełnienia wiąże się z ich wyższym zadowoleniem z życia, a spostrzegana jako ograniczenie dotychczasowych możliwości zmienia kierunek tej zależności na negatywny.
Hipoteza 2: Predyktorami zadowolenia z życia są perspektywy temporalne - przeszła pozytywna, teraźniejsza hedonistyczna, przyszła (związek ten będzie dodatni), przeszła negatywna, teraźniejsza fatalistyczna oraz odchylenie od zrównoważonej perspektywy (związek ten będzie ujemny).

Hipoteza 3: Poczucie dorosłości jest moderatorem związku pomiędzy perspektywami temporalnymi oraz odchyleniem od zrównoważonej perspektywy a zadowoleniem z życia-gdy dorosłość jest spostrzegana jest jako zadanie, wówczas wchodzi w interakcję z perspektywą przeszłą pozytywną i wzmacnia zadowolenie z życia, a gdy jest spostrzegana jako ograniczenie, wtedy wiąże się z perspektywą przeszłą negatywną, teraźniejszą fatalistyczną oraz odchyleniem od zrównoważonej perspektywy, osłabiając tym samym zadowolenie z życia.

\section{METODA}

\section{Osoby badane i procedura}

Przebadano łącznie 208 osób w przedziale wiekowym od 19 do 35 lat, w tym 154 kobiety i 54 mężczyzn. W badaniu brali udział młodzi dorośli z różnym wykształceniem (podstawowym, zawodowym, średnim, wyższym licencjackim, wyższym magisterskim) i różnym stażem pracy. Badanym rozesłano link dostępu (http://moje-ankiety.pl/respond-4880/sec-aiO4qoGj.html) do zestawu kwestionariuszy opublikowanych za pomocą serwisu ,moje-ankiety.pl". Zebrano 327 wypełnionych zestawów, spośród których wyeliminowano 119 badań niekompletnych (badania, w których brakowało danych demograficznych, zawierały niekompletne arkusze testowe; w większości były to jednak badania nieukończone). Średni wiek badanych to 25,45 lat $(\mathrm{SD}=3,17)$, a $65 \%$ osób w momencie badania nie przekroczyło 29. roku życia. Badana grupa składała się przede wszystkim z osób z wykształceniem wyższym magisterskim $(\mathrm{N}=122)$, średnim $(\mathrm{N}=49)$ oraz wyższym $\mathrm{z}$ tytułem licencjata $(\mathrm{N}=34)$, trzy osoby miały wykształcenie zawodowe. 


\section{Narzędzia}

Nasilenie ogólnego poczucia dorosłości zostało zbadane za pomocą Kwestionariusza Oceny Własnej Sytuacji Życiowej (KOWSŻ) - autorskiego narzędzia badawczego Wandy Zagórskiej (2012, źródło własne). Kwestionariusz ten został skonstruowany jako narzędzie służące określeniu momentu (miejsca) rozwojowego, w jakim znajduje się tzw. młody dorosły (czyli osoba w wieku od około 20-35 lat) w procesie własnego wchodzenia w dorosłość (często mającym postać tzw. moratorium psychospołecznego, w znaczeniu nadanym mu przez Eriksona, 1968). Kwestionariusz zbudowany jest z 16 pozycji. W wersji papierowej przyjmujac one postać wymiarów ciaggłych $\mathrm{z}$ opisanymi krańcami, na przykład „Zupełnie nie wyobrażam sobie mojego życia jako osoby dorosłej" vs. „Mam bardzo konkretną "wizję« mojego życia jako osoby dorosłej” (poz. 3), „Zasadnicze wybory życiowe są jeszcze przede mną" vs. „Dokonałem(-am) już zasadniczych wyborów życiowych" (poz. 10). Osoba badana ma za zadanie ustosunkować się do każdego ze stwierdzeń, stawiając pionową kreskę w wybranym przez siebie miejscu na poszczególnych skalach, mających postać odcinków o długości 10 centymetrów. W wersji oryginalnej odpowiedzi badanych są przekształcane na skalę porządkową z wartościami od -10 do 10 punktów. Ze względu na specyfikę badań za pośrednictwem internetu dokonano modyfikacji w sposobie wypełniania kwestionariusza oraz przekształcania wyników. Badani udzielali odpowiedzi za pomocą dyferencjału semantycznego. Mając do dyspozycji skalę z wartościami od 1 do 100, „umieszczali na niej siebie" poprzez ustawienie suwaka w wybranym miejscu na skali. W badaniach normalizacyjnych W. Zagórska (2004) za pomoca analizy czynnikowej uzyskała cztery składowe zmiennej poczucie dorosłości. Są to: obraz dorosłego Ja (czynnik I), perspektywa dorosłości (czynnik II), niezależność od rodziny/pochodzenia (czynnik III) oraz gotowość do podjęcia zadań dorosłości (czynnik IV). Rzetelność ( $\alpha$ Cronbacha) tych podskal kwestionariusza wynosi odpowiednio: .67; .85; .60; i .55. Ze względu na pilotażowy charakter techniki zastosowanie jej w niniejszej pracy poprzedzono ponownym wykonaniem analizy czynnikowej metodą głównych składowych z rotacją $\mathrm{Ob}-$ limin i uzyskano strukturę dwuczynnikową narzędzia. Dane z badania spełniły założenia analizy czynnikowej: test sferyczności Bartletta wykazał, że macierz korelacji nie jest macierzą jednostkową (por. Field, 2013, $\chi^{2}=915,978$, $\mathrm{p}<.001$, a miara KMO (Kaiser-Meyer-Olkin Measure of Sampling Adequacy) wynosiła .881. Analiza przekątnej (diagonal) macierzy przeciwobrazów korelacji (anti-image-correlation matrix), przedstawiająca wartości indywidualne miary KMO dla każdej poszczególnej zmiennej (wartości poza przekątną reprezentują korelację cząstkową między zmiennymi i powinny być jak najmniejsze), wykazała, że kwestionariusz spełnia wymagania miary KMO w stosunku do każdej pozycji z osobna. Żadne z twierdzeń nie powinno mieć wartości mniejszej niż .5 (Field, 2013). Miara ta dla poszczególnych pozycji wahała się od .568 do .848. W wyniku analizy czynnikowej otrzymano cztery składowe główne z wartością własną (eigenvalue) powyżej jedności, wyjaśniające łącznie 56,4\% wariancji. Mimo to na wykresie osypiska wyraźnie wyodrębniały się dwa czynniki wyjaśniające łącznie 41,1\% wariancji. Wszystkie ładunki czynnikowe zawarte w macierzy modelowej osiagnęły rekomendowaną wartość wyższą niż .40 (Stevens, 1992). Ponieważ wykres osypiska sugerował istnienie dwóch głównych czynników, chciano się upewnić, czy przypuszczenia dotyczące liczby czynników są słuszne, zastosowano więc analizę równoległą (Horn, 1965), wykorzystując program Marleya Watkinsa Monte Carlo PCA for Parallel Analysis (2000) przy 100 replikacjach (por. Tabachnick, Fidel, 2007). Wynik tej analizy stanowi określenie przeciętnych wartości własnych dla 100 losowo wybranych próbek. Kolejnym krokiem jest porównanie wartości własnych otrzymanych w wyniku analizy czynnikowej i analizy Monte Carlo, w wyniku czego wyodrębniono te czynniki, które wykazują wyższą wartość własną uzyskaną w wyniku analizy czynnikowej niż wartość uzyskana w wyniku analizy równoległej Monte Carlo. Wartość taką 
uzyskały dwa czynniki. Ostatecznie 10 pozycji utworzyło skalę „Dorosłość jako zadanie” (DZ - przykład pozycji: „Czuję się w pełni gotów(owa) do pracy zawodowej"; $\alpha$ Cronbacha $=.83)$. Czynnik drugi na podstawie analizy treści sześciu pozycji otrzymał nazwę „Dorosłość jako ograniczenie” (DO - przykład pozycji: „Niektóre z możliwych dróg życia są już dla mnie zamknięte"; $\alpha$ Cronbacha $=.66$ ).

Dwuczynnikową strukturę kwestionariusza uzasadniają też wyniki badań wskazujące na dwoistości zjawisk dotyczących wczesnej dorosłości. Na przykład niektórzy badacze twierdzą, że poczucie dobrostanu we wczesnej dorosłości jest wyraźnie wyższe niż jest w okresie dojrzewania (Galambos i in., 2006). Inni z kolei określają tę fazę jako czas nasilania się objawów lęku i depresji (Reinherz i in., 2003). Paradoksalnie wczesna dorosłość jest zarówno ,wiekiem możliwości” (Arnett, 2000, 2007), jak i niepewności czy obaw związanych z przyszłością (Côté, 2014; MacMillan, 2007). Jak pisze Schwartz (2016) mamy do czynienia ze zjawiskiem „dwóch twarzy” dorosłości.

Pomiaru perspektywy temporalnej dokonano za pomoca Kwestionariusza Postrzegania Czasu - KPC (The Zimbardo Time Perspective Inventory) P.G. Zimbarda i J.N. Boyda (2009). Składa się on z 56 pozycji ocenianych na pięciostopniowej skali Likerta (od zupełnie nieodnoszących się do w pełni odnoszących się do respondenta), tworzących pięć skal mierzących koncentrację na poszczególnych obszarach czasu: przeszła negatywna perspektywa postrzegania czasu (10 pozycji, $\alpha$ Cronbacha $=.82)$, przeszła pozytywna perspektywa postrzegania czasu $(9$ pozycji, $\alpha$ Cronbacha $=$ .80), teraźniejsza fatalistyczna perspektywa postrzegania czasu $(9$ pozycji, $\alpha$ Cronbacha $=$ .74), teraźniejsza hedonistyczna perspektywa postrzegania czasu (15 pozycji, $\alpha$ Cronbacha $=$ .79) i przyszła perspektywa postrzegania czasu (13 pozycji, $\alpha$ Cronbacha $=.77)$. Wszystkie wskaźniki rzetelności obliczono na podstawie badań własnych. Dodatkowo obliczono wskaźnik odchylenia od zrównoważonej perspektywy temporalnej (OZTP) opierając się na następującej formule (Stolarski i in., 2011):
$\mathrm{OZTP}=\sqrt{\begin{array}{l}(o P N-e P N)^{2}+(o P P-e P P)^{2}+ \\ +(o T F-e T F)^{2}(o T H-e T H)^{2}+ \\ +(o P-e P)^{2} ;\end{array}}$

gdzie $o$ oznacza optymalny wskaźnik dla danej perspektywy, e zaś wskaźnik uzyskany przez badanego. Optymalne wskaźniki dla poszczególnych perspektyw, zostały opracowane w badaniach międzykulturowych przez P.G. Zimbarda i J.N. Boyda (www.thetimeparadox. com/surveys). Wynoszą one: dla perspektywy przeszłej negatywnej $(P N)-1.95$, przeszłej pozytywnej $(P P)-4.60$, teraźniejszej fatalistycznej $(T F)-1.50$, teraźniejszej hedonistycznej $(T H)-3.90$, przyszłej $(P)-4.00$. Wybór tego wskaźnika w niniejszym opracowaniu wynika z tego, iż jest on silniejszym predyktorem dobrostanu niż pozostałe, opisywane wcześniej dwa wskaźniki ZTP (Boniwell i in. 2010; Drake $i$ in. 2008; Zhang i in., 2013).

Do oceny ogólnego wskaźnika poczucia zadowolenia z życia osoby badanej użyto adaptacji Skali Satysfakcji z Życia - SWLS (The Satisfaction with Life Scale; SWLS), autorstwa Eda Dienera, Roberta A. Emmonsa, Randy'ego J. Larsona i Sharon Griffin, w adaptacji Zygfryda Juczyńskiego (2009). Skala ta mierzy poznawcze aspekty subiektywnego poczucia dobrostanu (ang. subjective well-being). Zawiera pięć stwierdzeń, którym badany przyporządkowuje punkty od 1 do 7, w zależności od stopnia, w jakim zgadza się z każdym ze stwierdzeń. Oceniane za pomocą SWLS zadowolenie z życia wyraża się w poczuciu satysfakcji z osobistych osiągnięć. Wskaźnik rzetelności $\alpha$ Cronbacha dla SWLS wynosi .81.

\section{WYNIKI}

W pierwszym kroku przeprowadzono analizę normalności rozkładu wszystkich zmiennych i uzyskano akceptowalne istotności w teście Kołmogorowa-Smirnowa i Shapiro-Wilka (powyżej .05).

Wśród statystyk opisujących percepcję dorosłości (średnie i odchylenie standardowe) 
wyższe wyniki uzyskują badani w kategorii „Dorosłość jako ograniczenie” niż w kategorii „Dorosłość jako zadanie”. Najsilniej reprezentowanymi orientacjami temporalnymi sa przeszła pozytywna, przyszła i teraźniejsza hedonistyczna, a najsłabiej przeszła negatywna i teraźniejsza fatalistyczna.

W dalszej kolejności sprawdzono, czy istnieją różnice w uzyskiwanych wynikach pomiędzy kobietami a mężczyznami. Ze względu na dużą różnicę pomiędzy liczebnościami grup kobiet i mężczyzn przeprowadzono test jednorodności wariancji oraz mocny test równości średnich z poprawką Browna i Forsythe'a. Uzyskano istotności powyżej .05, co pozwoliło na zastosowanie analizy ANOVA. Wykazała ona tylko jedną różnicę w zakresie zmiennej „Dorosłość jako ograniczenie": mężczyźni $(\mathrm{M}=50.77, \mathrm{SD}=$ 17.98) uzyskali istotnie wyższe wyniki niż kobiety $(\mathrm{M}=40.67, \mathrm{SD}=13.05)[\mathrm{F}(1,206)=19$, $\left.45, \mathrm{p}<.001 ; \omega^{2}=.06\right]$. Efekt $\omega^{2}$ można uznać za przeciętny (Field, 2013, s. 474). Dalsze ana- lizy były zatem wykonywane z wykorzystaniem wyników całej grupy.

W następnym etapie analizy weryfikowano pierwsze dwie hipotezy. Obliczono korelacje $r$-Pearsona pomiędzy zmiennymi (tabela 1) i uzyskano dwie zależności prostoliniowe. Jak przewidywano, dorosłość spostrzegana jako zadanie umiarkowanie koreluje dodatnio z zadowoleniem z życia, a w wypadku dorosłości spostrzeganej jako ograniczenie te zależności mają podobną siłę, ale odwrotny kierunek, co potwierdza sformułowane przypuszczenia. W celu weryfikacji drugiej hipotezy wykonano dwie analizy regresji. W pierwszym wypadku zastosowano wielozmiennową analizę regresji metodą wprowadzania, w której predyktorami było pięć perspektyw temporalnych, a zmienną zależną zadowolenie z życia mierzone kwestionariuszem SWLS. Wszystkie pięć perspektyw temporalnych wyjaśnia 32\% wariancji zmiennej wyników skali SWLS. Wbrew przypuszczeniom jednak, jak pokazuje tabela 2, tylko perspek-

Tabela 1. Analiza korelacji $r$-Pearsona między badanymi zmiennymi oraz średnie (M), odchylenia standardowe (SD), wartości minimalne (Min) i maksymalne (Max) poszczególnych zmiennych

\begin{tabular}{|c|c|c|c|c|c|c|c|c|c|}
\hline & 1 & 2 & 3 & 4 & 5 & 6 & 7 & 8 & 9 \\
\hline 1. SWLS & 1 & & & & & & & & \\
\hline 2. $\mathrm{DZ}$ & $.38 * *$ & 1 & & & & & & & \\
\hline 3. DO & $-.36 * *$ & .05 & 1 & & & & & & \\
\hline 4. $\mathrm{PN}$ & $-.49 * *$ & $-.34 * *$ & $.20 * *$ & 1 & & & & & \\
\hline 5. PP & $.38 * *$ & .08 & $.37 * *$ & $-.30 * *$ & 1 & & & & \\
\hline 6. TH & -.03 & $.28 * *$ & -.02 & .08 & .08 & 1 & & & \\
\hline 7. TF & $-.29 * *$ & $-.36^{* *}$ & .08 & $.36^{* *}$ & -.06 & $.34 * *$ & 1 & & \\
\hline 8. P & $.15^{*}$ & $.31 * *$ & -.09 & -.02 & -.03 & $-.31 * *$ & $-.40 * *$ & 1 & \\
\hline 9. OZPT & $-.53 * *$ & $-.41 * *$ & $.32 * *$ & $.75 * *$ & $-.57 * *$ & .09 & $.68 * *$ & $-.32 * *$ & 1 \\
\hline M & 20.64 & 60.00 & 43.29 & 3.07 & 3.57 & 3.43 & 2.81 & 3.52 & 2.34 \\
\hline SD & 5.77 & 16.46 & 15.11 & .61 & .53 & .46 & .55 & .49 & .64 \\
\hline Min & 6.00 & 18.40 & 10.50 & 1.70 & 2.11 & 2.13 & 1.44 & 2.23 & .83 \\
\hline Max & 35.00 & 97.90 & 100.00 & 4.50 & 4.89 & 4.73 & 4.78 & 4.62 & 3.99 \\
\hline
\end{tabular}

SWLS - zadowolenie z życia, DZ - dorosłość jako zadanie, DO - dorosłość jako ograniczenie, PN - perspektywa przeszła negatywna, $\mathrm{PP}$ - perspektywa przeszła pozytywna, TH - perspektywa teraźniejsza hedonistyczna, $\mathrm{TF}$ - perspektywa teraźniejsza fatalistyczna, P - perspektywa przyszła; OZPT - odchylenie od zrównoważonej perspektywy temporalnej;

$* \mathrm{p}<.05 ; * * \mathrm{p}<.01$ 
Tabela 2. Współczynniki wielozmiennowej regresji uzupełnione o kwadrat współczynnika korelacji semicząstkowej $\left(s r^{2}\right)$ predyktorów zadowolenia z życia (SWLS)

\begin{tabular}{lcccc}
\hline & $\mathbf{b}$ & $\mathbf{S E}$ & $\boldsymbol{\beta}$ & $\mathbf{s r}^{\mathbf{2}}$ \\
\hline $\mathbf{P N}$ & -3.604 & .621 & $-.379^{* * *}$ & .110 \\
$\mathbf{P P}$ & 2.826 & .656 & $.261^{* * *}$ & .059 \\
TH & .702 & .779 & .056 & .003 \\
$\mathbf{T F}$ & -1.081 & .741 & -.102 & .007 \\
$\mathbf{P}$ & 1.499 & .761 & $.127^{*}$ & .013 \\
\hline
\end{tabular}

$R^{2}=.33$, skorygowany $R^{2}=.32, \mathrm{~F}(5,202)=20.30, \mathrm{p}<.001 ; * \mathrm{p}<.05 ; * * * \mathrm{p}<.001 ;$

oznaczenia zmiennych jak w tabeli 1

tywa przeszła negatywna, przeszła pozytywna i przyszła wyjaśniają istotną statystycznie proporcję wariancji. Ze względu na współliniowość zdiagnozowaną pomiędzy perspektywami temporalnymi a odchyleniem od zrównoważonej perspektywy - OZPT (VIF = 14.73 wynika $\mathrm{z}$ formuły, na podstawie której skonstruowano tę ostatnią zmienną) przeprowadzono regresję prosta, w której predyktorem zadowolenia z życia była zmienna OZPT. Wyjaśnia ona $28 \%$ zmiennej zależnej i proporcja ta jest istotna statystycznie (tabela 3 ).

Aby zweryfikować hipotezę dotyczącą związku orientacji temporalnych z zadowoleniem życia $\mathrm{z}$ uwzględnieniem takich moderatorów, jak „Dorosłość jako zadanie” (DZ) oraz „Dorosłość jako ograniczenie” (DO), wykonano analizy moderacji dla zmiennej zależnej: zadowolenie życia (ZŻ) z zastosowaniem metody makro PROCESS Hayesa, opracowanej dla programu IBM SPSS 25 (process.spd).Wyniki interpretowano zgodnie $\mathrm{z}$ zaleceniami autora procedury (Hayes, 2018). Testowano sześć modeli, analizując interakcje między sześcioma zmiennymi niezależnymi, na które skła- dało się pięć perspektyw temporalnych oraz OZPT, a moderatorem określającym poczucie dorosłości - jako zadanie (DZ) a zmienna zależną - zadowolenie z życia. Tę samą procedurę powtórzono $\mathrm{z}$ wprowadzeniem moderatora poczucie dorosłości jako ograniczenie (DO). Łącznie przetestowano 12 modeli. Zmienne niezależne wycentrowano wokół tzw. średniej globalnej (grand mean centered). Wycentrowanie zmiennej wokół średniej globalnej oznacza, że współczynniki są wyrażone są w odniesieniu do średniej dla całej próby, a stała w modelu (intercept) wyraża wartość oczekiwaną dla całej próby dla danego predyktora lub zestawu predyktorów.

Do oceny kierunku i siły interakcji wybrano trzy przedziały moderatora (poziom średni, jedno odchylenie standardowe powyżej i poniżej średniej). Jeśli nachylenie linii regresji jest różne w podzbiorach moderatora to znaczy, że możemy mieć do czynienia $\mathrm{z}$ istotnym efektem moderacji (Baron, Kenny, 1986). Dzięki temu możliwe jest poszukiwanie odpowiedzi na pytanie, kiedy i w jakich warunkach zachodzi dana zależność.

Tabela 3. Współczynniki regresji prostej uzupełnione o kwadrat współczynnika korelacji semicząstkowej $(s r 2)$ predyktora zadowolenia z życia (SWLS)

\begin{tabular}{ccccc}
\hline & $\mathrm{b}$ & $\mathrm{SE}$ & $\beta$ & $\mathrm{sr}^{2}$ \\
\hline OZPT & -4.776 & .528 & $-.533 * * *$ & .284 \\
\hline
\end{tabular}

$R^{2}=.28$, skorygowany $R^{2}=.28, \mathrm{~F}(1,206)=81.78, \mathrm{p}<.001 ; * \mathrm{p}<.05 ; * * * \mathrm{p}<.001 ;$

oznaczenie zmiennej jak w tabeli 1 
Efekt moderacji uzyskano w trzech modelach (zmienną zależną zawsze było zadowolenie życia). W pierwszym z nich (tabela 4) o współczynniku determinacji $R^{2}=.32$ efekt interakcji pojawił się w wypadku perspektywy przeszłej negatywnej oraz dorosłości spostrzeganej jako ograniczenie. Analiza wykazała, że model ze składnikiem interakcyjnym jest dobrze dopasowany do danych. Związek zadowolenia z życia z perspektywą przeszłą negatywną okazał się ujemny. Oznacza to, że wysokie wyniki w zakresie tej zmiennej obniżają zadowolenie z życia. Zależność o tym samym kierunku, choć o mniejszej sile, występuje w wypadku zmiennej dorosłość jako ograniczenie. Efekt interakcji pomiędzy tymi dwiema zmiennymi jest istotny statystycznie i również ujemny. Występuje on w wypadku wszystkich trzech poziomów zmiennej dorosłość jako ograniczenie - gdy jej wyniki są niskie $(b=-.306, t(204)=-3.718$, $p<.001)$, średnie $(b=-.406, t(204)=-7.215$, $p<.001)$ oraz wysokie $(b=-.507, t(204)=$ $-6.888, p<.001)$. We wszystkich wypadkach (rysunek 1) moderator wzmacnia ujemny związek pomiędzy orientacją przeszłą negatywną a satysfakcją z życia, a przyrost wyjaśnianej wariancji wynosi $2 \%$.

Drugi dopasowany do danych model ze składnikiem interakcyjnym o współczynniku determinacji $R^{2}=.33$ dotyczy efektu interakcji w odniesieniu do odchylenia od zrównoważonej perspektywy temporalnej oraz dorosłości spostrzeganej jako ograniczenie (tabela 5). Związek OZPT z zadowoleniem z życia jest ujemny, co oznacza, że wraz ze spadkiem odchylenia od zrównoważonej perspektywy temporalnej rośnie zadowolenie z życia. Ten sam kierunek zależności obserwujemy w odniesieniu do związku zmiennej zależnej ze zmienną dorosłość jako ograniczenie. Związek z zadowoleniem z życia o tym samym kierunku dotyczy też składnika interakcyjnego. Efekt interakcji pomiędzy tymi zmiennymi jest istotny statystycznie i również ujemny. Ponownie występuje on w wypadku wszystkich trzech poziomów zmiennej dorosłość jako ograniczenie (rysunek 3) - gdy jej wyniki są niskie $(b=-3.149, t(204)=-3.903$, $p<.001)$, średnie $(b=-4.041, t(204)=-7.395$, $p<.001)$ oraz wysokie $(b=-4.933, t(204)=$ $-7.114, p<.001)$. We wszystkich wypadkach moderator wzmacnia ujemny związek pomiędzy OZPT i satysfakcją z życia, a przyrost wyjaśnianej wariancji wynosi $4 \%$.

Trzeci dopasowany do danych model ze składnikiem interakcyjnym o współczynniku determinacji $R^{2}=.24$ prezentuje efekt interakcji w odniesieniu do pespektywy przeszłej pozytywnej oraz dorosłości spostrzeganej jako zadanie (tabela 6). Związek z zadowoleniem z życia perspektywy przeszłej pozytywnej oraz dorosłości spostrzeganej jako zadanie okazał się dodatni. Efekt interakcji pomiędzy tymi zmiennymi jest jednak ujemny i występuje tylko w wypadku dwóch poziomów zmiennej dorosłość spostrzegana jako zadanie - gdy jej wyniki są niskie $(b=.576, t(204)=4.620, p<.001)$ i średnie $(b=.422, t(204)=4.383, p<.001)$. Gdy wyniki są wysokie, efekt jest nieistotny

Tabela 4. Dopasowany do danych liniowy model predyktorów zadowolenia z życia (SWLS) - poczucia dorosłości jako ograniczenia (moderator W) i perspektywy temporalnej przeszłej negatywnej (zmienna niezależna $\mathrm{X}$ )

\begin{tabular}{cccccc}
\hline & & b & SE & t & P \\
\hline$R^{2}=.32 ; \mathrm{F}(3,204)=32.539, \mathrm{p}<.001$ & & & & & \\
& Stała & 20.768 & .338 & 61.409 & $<.001$ \\
& PN (X) & -.406 & .056 & -7.215 & $<.001$ \\
& DO (W) & -.092 & .023 & -4.004 & $<.001$ \\
& PN x DO $(\mathrm{XW})$ & -.007 & .004 & -1.859 & .05 \\
\hline
\end{tabular}

Oznaczenia zmiennych jak w tabeli 1 , zmiana $R^{2}=.02$ 


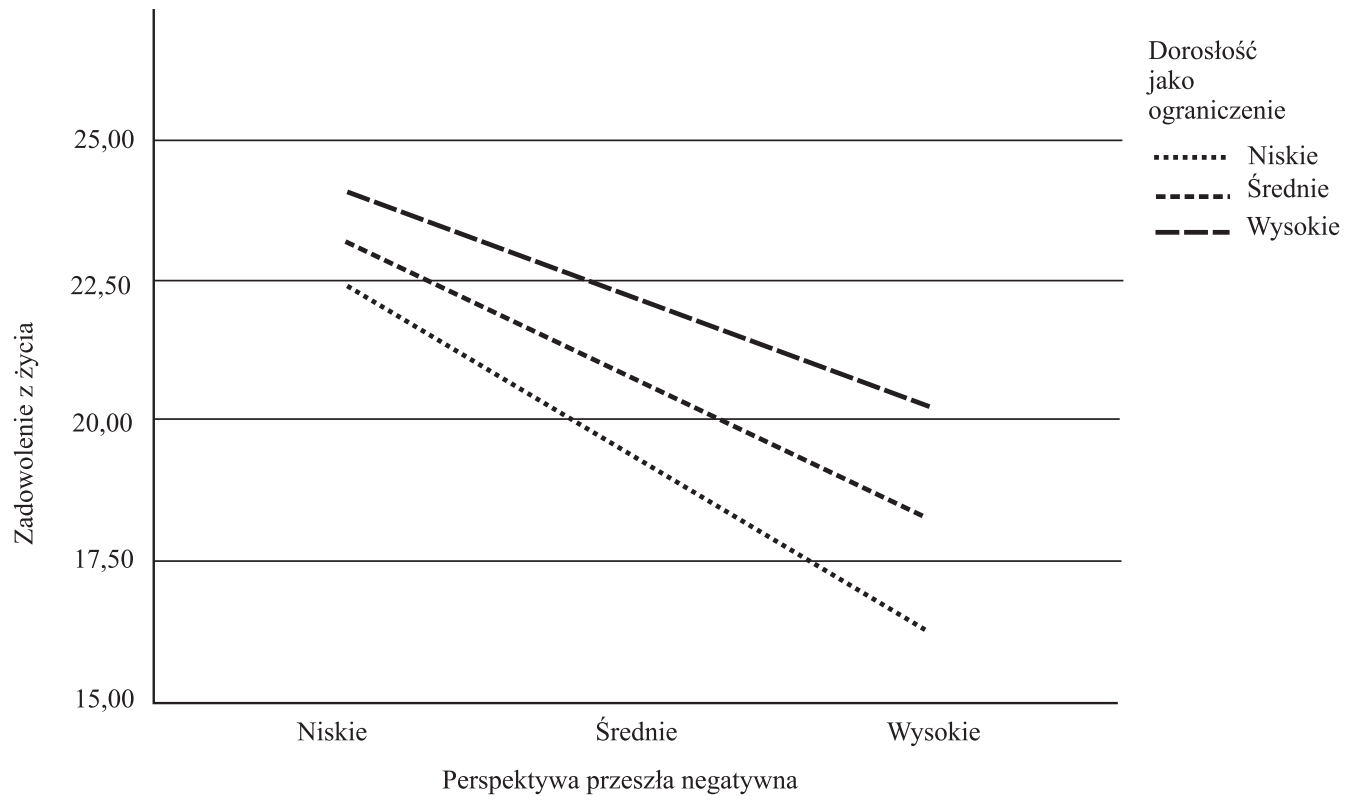

Rysunek 1. Wielokrotny wykres liniowy obrazujący relację pomiędzy zmienną perspektywa przeszła negatywna a zmienną zadowolenie z życia w trzech podgrupach - osób o niskich, średnich i wysokich wynikach zmiennej dorosłość jako ograniczenie

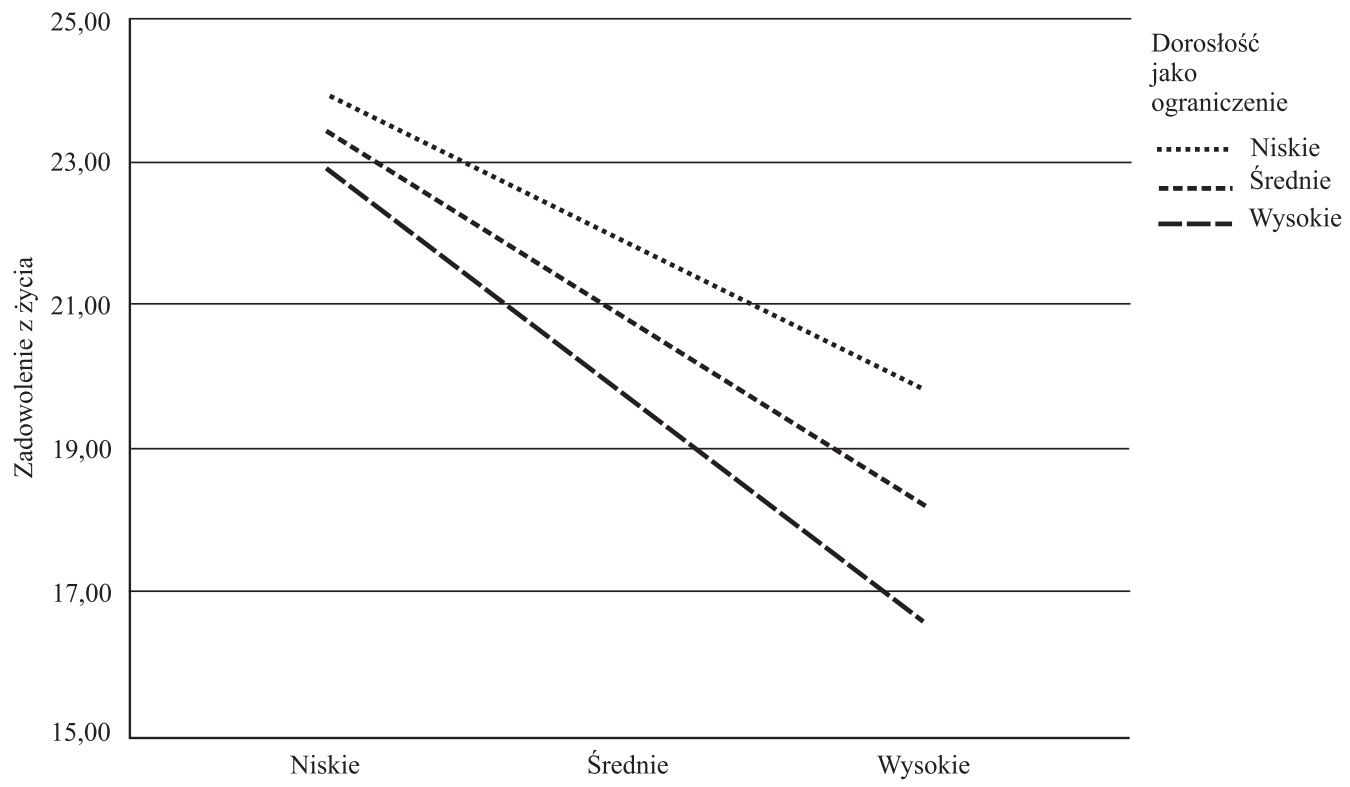

Odchylenie od zrównoważonej perspektywy temporalnej (OZPT)

Rysunek 2. Wielokrotny wykres liniowy obrazujący relację pomiędzy zmienną odchylenie od zrównoważonej perspektywy temporalnej a zmienną zadowolenie z życia w trzech podgrupach - osób o niskich, średnich i wysokich wynikach zmiennej dorosłość jako ograniczenie 


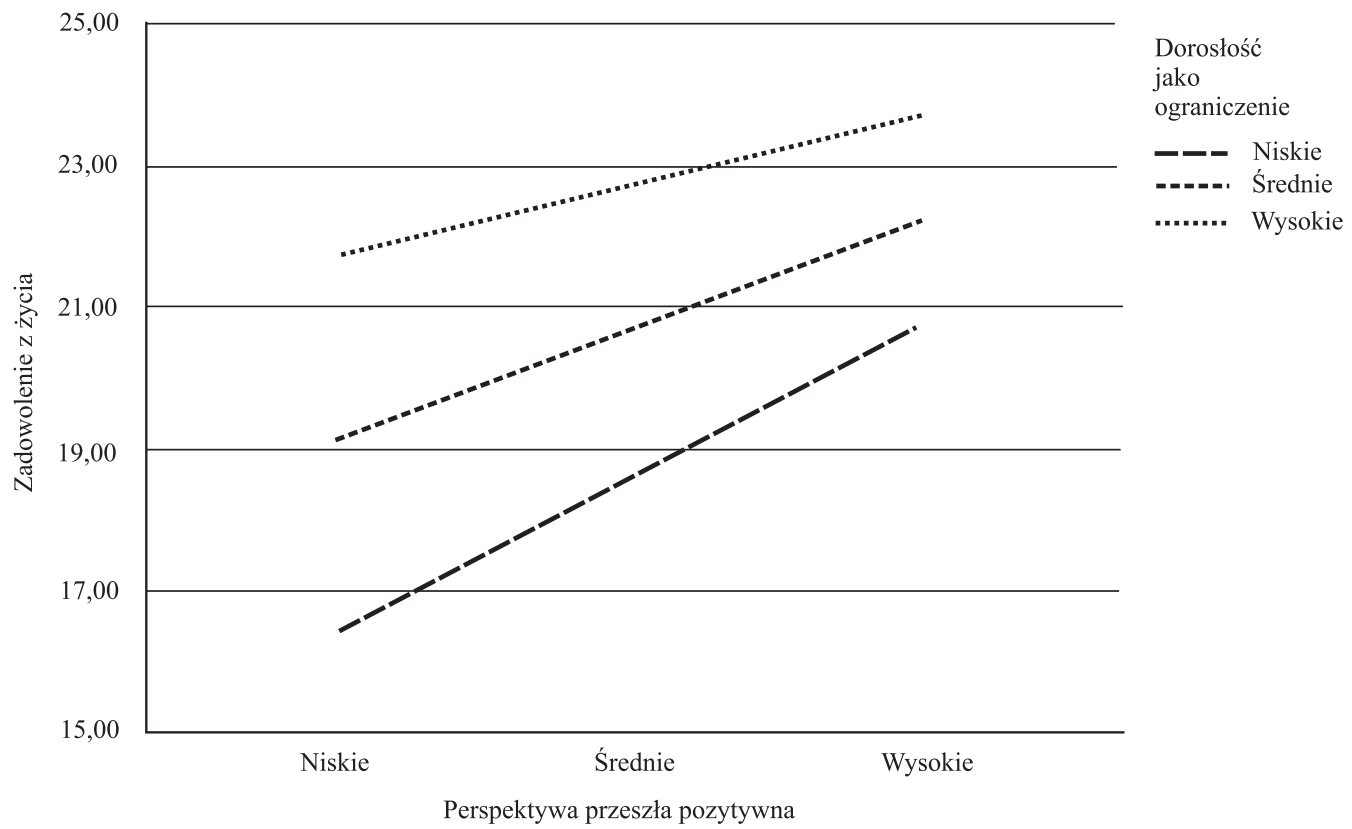

Rysunek 3. Wielokrotny wykres liniowy obrazujący relację pomiędzy zmienną perspektywa przeszła pozytywna a zmienną zadowolenie z życia w trzech podgrupach - osób o niskich, średnich i wysokich wynikach zmiennej dorosłość jako zadanie

Tabela 5. Dopasowany do danych liniowy model predyktorów zadowolenia z życia (SWLS) - poczucia dorosłości jako ograniczenia (moderator W) i odchylenia od zrównoważonej perspektywy temporalnej OZPT (zmienna niezależna X)

\begin{tabular}{lccccc}
\hline & & b & SE & t & P \\
\hline$R^{2}=.33 ; \mathrm{F}(3,204)=33.946, \mathrm{p}<.001$ & & & & & \\
& Stała & 20.826 & .346 & 60.243 & $<.001$ \\
& OZPT (X) & -4.404 & .547 & -7.395 & $<.001$ \\
& DO (W) & -.072 & .024 & -3.044 & $<.01$ \\
& OZTP x DO $(\mathrm{XW})$ & -.060 & .034 & -1.726 & .05 \\
\hline
\end{tabular}

Oznaczenia zmiennych jak w tabeli 1 , zmiana $R^{2}=.04$

statystycznie $(b=.270, t(204)=1.861, p=$ .06). Przyrost wyjaśnianej wariancji wynosi 4\%. Zależności te ilustruje rysunek 3 . Nieistotna statystycznie wartość moderatora zawiera się, zgodnie z procedurą Johnsona-Neymana, w 17,31\% górnej części wyników. Oznacza to po odczytaniu z tabeli częstości odpowiadających wyników - że spostrzeganie dorosłości jako zadania wzmacnia efekt perspektywy przeszłej pozytywnej na zadowolenie z życia tylko wówczas, gdy na skali spostrzegania dorosłości zawierającej się w wartościach od 0 do 100 osoby badane uzyskują wyniki do 75 punktów. Wynik powyżej tej granicy nie wzmacnia dodatniego efektu perspektywy przeszłej pozytywnej. 
Tabela 6. Dopasowany do danych liniowy model predyktorów zadowolenia z życia (SWLS) - poczucia dorosłości jako zadania (moderator W) i perspektywy temporalnej przeszłej pozytywnej (zmienna niezależna X)

\begin{tabular}{cccccc}
\hline & & b & SE & t & P \\
\hline$R^{2}=.24 ; \mathrm{F}(3,204)=20.961, \mathrm{p}<.001$ & & & & & \\
& Stała & 20.676 & .353 & 58.559 & $<.001$ \\
& PP $(\mathrm{X})$ & .422 & .059 & 4.383 & $<.001$ \\
& $\mathrm{DZ}(\mathrm{W})$ & .126 & .022 & 5.844 & $<.001$ \\
& PP x DZ $(\mathrm{XW})$ & -.009 & .006 & -1.613 & .05 \\
\hline
\end{tabular}

Oznaczenia zmiennych jak w tabeli 1 , zmiana $R^{2}=.02$

\section{DYSKUSJA}

Celem niniejszego projektu badawczego było zidentyfikowanie zależności między perspektywami temporalnymi młodych dorosłych a ich zadowoleniem z życia. Weryfikowano też szczególną rolę moderatora tego związku, jakim jest dwojako spostrzegane przez młode osoby poczucie dorosłości - jako zadanie i jako ograniczenie. Wstępne wyniki zaprezentowane w analizach opisowych perspektyw temporalnych potwierdzają sekwencję wyników uzyskanych w innych badaniach z udziałem młodych dorosłych (Boniwell i in. 2010; Drake i in. 208, Stolarski i in., 2011; Zhang i in. 2013), które wykazują w tej grupie przewage pozytywnych kategorii percepcji czasu nad negatywnymi. Poza tym widoczna jest przewaga wyników świadczących o spostrzeganiu dorosłości raczej jako zadania rozwojowego niż jako fazy zamykającej dostęp do przywilejów dzieciństwa. Wyniki te moga sugerować, że tłem większości zmian rozwojowych, jakie stoją przed młodymi osobami, są doznania aprobujące dotychczasowe i obecne doświadczenia życiowe oraz zakładające korzystne scenariusze przebiegu nadchodzących zdarzeń.

Zgodnie z przewidywaniami dorosłość spostrzegana jako zadanie okazała się pozytywnie związana z zadowoleniem z życia w przeciwieństwie do dorosłości spostrzeganej jako ograniczenie, której relacja $\mathrm{z}$ zadowoleniem z życia była silna, ale miała kierunek odwrotny.
Zależność ta nie zaskakuje, ponieważ dojrzała postawa zadaniowa może wynikać z pozytywnej oceny własnej zaradności i determinacji w podejmowanych działaniach, a to z kolei sprzyja poczuciu dobrostanu psychicznego.

Tak jak zakładano, najbardziej krytyczne dla predykcji zadowolenia życia okazują się negatywna i pozytywna wizja przeszłości oraz ukierunkowanie na przyszłość (choć w tym wypadku proporcja wyjaśnianej wariancji jest najmniejsza). Jest to wynik spójny z wynikami podobnych badań (Desmyter, De Raedt, 2012; Van Beek i in., 2011; Molinari i in., 2016). Jak zauważyli cytowani badacze, związek między perspektywą negatywną przeszłą a samopoczuciem jest silny i może być dwukierunkowy, a ludzie, którzy doświadczają objawów psychicznego cierpienia, prawdopodobnie częściej rozmyślają na temat przykrych doświadczeń z przeszłości. Możliwe jest również, że podobna dwukierunkowa zależność występuje w przypadku dobrego samopoczucia psychicznego i perspektywy przeszłej pozytywnej - osoby o wysokim poziomie dobrostanu są skłonne do korzystania z pozytywnych wspomnień w życiu codziennym i do interpretacji obecnych doświadczeń w pozytywnym świetle, zwiększając tym samym poziom perspektywy przeszłej pozytywnej. Stosunkowo niski poziom predykcji w wypadku perspektywy przyszłej można wiązać z podwyższonym poczuciem lęku i koncentracji na trudnościach (Drake i in., 2008; Zimbardo, Boniwell, 2007). 
Wbrew przewidywaniom najciekawszy wydaje się jednak całkowity brak efektu predykcji ze strony perspektywy teraźniejszej hedonistycznej. Nie jest on zgodny z przekonaniem, że hedoniści wyznają zasadę carpe diem, poszukują przyjemności, nagród, kontaktów interpersonalnych, co skutkuje radością życia (Zimbardo, Boyd, 1999; Zhang i in. 2013); nie pokrywa się również z wynikami badań wykazujących negatywny związek hedonizmu z poczuciem szczęścia (Drake i in., 2008). Podobne wyniki uzyskała natomiast Elisabeth Temple (2013) wskazując, że perspektywa przeszła negatywna jest główną zmienna wyjaśniającą psychologiczne różnice w zakresie dobrostanu między jednostkami; drugim z kolei istotnym predyktorem okazała się perspektywa przeszła pozytywna, przy całkowitym braku efektu ze strony perspektywy teraźniejszej hedonistycznej. Biorąc pod uwagę niskie korelacje z wynikami SWLS perspektywy teraźniejszej hedonistycznej, nie jest zaskoczeniem to, że okazała się ona nieistotnym predyktorem zadowolenia z życia, dziwi jednak brak istotnego związku zadowolenia z życia i perspektywy teraźniejszej fatalistycznej. Być może wynika to ze wspólnej wariancji tej perspektywy i perspektywy przeszłej negatywnej, ponieważ obie korelująze sobą na umiarkowanym, ale istotnym statystycznie poziomie.

Wyjaśnienia dysproporcji w zakresie roli perspektyw temporalnych w kreowaniu dobrostanu mogą dostarczyć Kerry F. Cunningham, Jia Wei Zhang i Ryan T. Howell (2015). Sugerują oni, że perspektywy czasowe wpływają na poczucie dobrostanu zarówno bezpośrednio, jak i pośrednio. Perspektywy przeszłe mają bezpośredni wpływ na to, jak ludzie oceniają swoje zadowolenie z życia, podczas gdy perspektywy przyszłe wpływają na poczucie szczęścia poprzez to, jak ludzie oceniają swoje szanse w przyszłości. Również perspektywy temporalne teraźniejsze, w tym hedonistyczna, mogą wpływać na poczucie dobrostanu pośrednio, kształtując zachowania, które podnoszą jakość życia, co z kolei wpływa na lepsze samopoczucie, stąd być może brak efektu predykcji w niniejszych badaniach.

Najsilniejszym predyktorem zadowolenia z życia okazało się odchylenie od zrównowa- żonej perspektywy temporalnej, co jest zbieżne $\mathrm{z}$ wynikami prac wielu autorów (Boniwell $\mathrm{i}$ in., 2010; Drake $\mathrm{i}$ in., 2008; Zhang i in., 2013), a także ze stwierdzeniem P.G. Zimbarda i J.N. Boyda (1999), że zrównoważona perspektywa czasowa jest warunkiem zdrowia fizycznego i psychicznego.

Prezentowane $w$ artykule badania wzbogaciły analizę bezpośrednich związków pomiędzy perspektywami temporalnymi a zadowoleniem z życia o aspekt rozwojowy; ujawniły także moderujący efekt, jaki wywiera na tę relację sposób spostrzegania dorosłości przez młodych ludzi, którzy nie są już adolescentami, ale jednocześnie nie zrealizowali jeszcze wszystkich zadań dorosłości. Okazuje się, że spostrzeganie dorosłości jako ograniczenia wraz z dominacją perspektywy przeszłej negatywnej zgodnie z przewidywaniami osłabia zadowolenie z życia na wszystkich poziomach oddziaływania moderatora. Podobny efekt rozwojowy daje się zaobserwować w wypadku interakcji odchylenia od zrównoważonej perspektywy temporalnej oraz dorosłości spostrzeganej jako ograniczenie. Nie zaobserwowano go jednak w wypadku interakcji OZPT z perspektywą teraźniejszą fatalistyczna, co potwierdza powyższe ustalenia dotyczące dominującej roli perspektyw przeszłych w przewidywaniu zadowolenia z życia. Dorosłość spostrzegana jako zadanie również daje efekt interakcyjny z perspektywą przeszła, tym razem pozytywna, choć z pewnymi ograniczeniami co do poziomu składnika interakcyjnego. Zadowalający w odniesieniu do zadowolenia z życia efekt jest widoczny tylko wówczas, gdy spostrzeganie dorosłości jako zadania jest na poziomie niskim lub średnim. Nadmierna koncentracja na celach i zadaniach rozwojowych okazuje się więc niekorzystna, podobnie jak to dzieje się w wypadku dominacji perspektywy przyszłej (Zimbardo, Boyd, 1999). Niewątpliwie samo poczucie dorosłości jest wynikiem akumulacji doświadczeń z przeszłości, zarówno pozytywnych, jak i negatywnych, o czym zresztą świadczą wysokie korelacje pomiędzy tymi grupami zmiennych. Zależność ta może mieć charakter dwukierunkowy i być może percepcja zarówno zagrożeń, jak i nadziei związanych z realizacją kolejnych zadań rozwo- 
jowych powoduje, że akumulacja pozytywnych lub negatywnych doświadczeń staje się mniej znacząca dla dobrego samopoczucia młodych dorosłych, tym bardziej że są oni grupą wiekową intensywnie skupioną na najbliższym horyzoncie czasowym (Fingerman, Perlmutter, 1995).

Chociaż prezentowane badania ujawniły wiele interesujących faktów, mają one pewne ograniczenia, o których warto wspomnieć w kontekście przyszłych prac badawczych. Po pierwsze, ponieważ wszystkie dane zebrano za pomocą kwestionariuszy, może to skutkować błędem wspólnej wariancji. Nadal jednak metody samoopisowe są uważane za najbardziej odpowiednie do gromadzenia informacji na temat subiektywnego pojmowania procesu rozwoju. Jednym z ważnych uzupełnień może się okazać strategia longi- tudinalna, w której odpowiednie zmienne są wielokrotnie oceniane w krótkich odstępach czasu. Po drugie, około $75 \%$ osób badanych stanowiły kobiety, co może modyfikować definicje kryteriów dorosłości, co potwierdzają badania Anny Oleszkowicz i Anny Miszteli (2015), w których kobiety formułowały więcej markerów dorosłości niż mężczyźni. W przyszłych badaniach niezbędne jest zatem większe zróżnicowanie grupy respondentów. Po trzecie, badanie perspektyw temporalnych warto wzbogacić o informacje biograficzne, które mogłyby wyjaśnić tło tworzenia się postaw jednostek wobec czasu. Stosowany w niniejszym opracowaniu kwestionariusz ZTPI nie pozwala wyjaśnić różnic pomiędzy wynikami z uwzględnieniem wagi rodzaju doświadczeń życiowych oraz ich umiejscowienia w czasie.

\section{PRZYPIS}

1 W wykorzystanej w niniejszym artykule koncepcji Zimbarda i Boyda (1999) perspektywę temporalną definiuje się jako tendencję do skupiania się na przeszłości, teraźniejszości, lub przyszłości w połączeniu z oceną pozytywną lub negatywną określonego wymiaru czasu. Złożoność tego pojęcia odzwierciedla choćby opis narzędzia do badania temporalności, zawarty w tym samym artykule (Zimbardo, Boyd, 1999, s. 1273) „Pozycje skali reprezentują twierdzenia dotyczące przekonań, preferencji i wartości jednostki dotyczące jej doświadczeń związanych z percepcją czasu" (tłum. własne). Również Shipp, Edwards i Schurer-Lambert (2009) traktują perspektywę czasową jako konstrukt wielowymiarowy, a Lasane i O’Donnell (2005) podkreślają, że składają się na niego trzy aspekty: poznawczy, afektywny i behawioralny. Pojawiają się zatem - na razie nieliczne nawet wśród badaczy wykorzystujących koncepcję Zimbarda - próby oceny perspektywy czasowej niezależnie od innych zmiennych psychologicznych (Worrell i in., 2018), tak by ograniczyć jej powiązanie z wartościowaniem czasu.

\section{BIBLIOGRAFIA}

Adelabu, D.H. (2007), Time perspective and school memberschip as correlates to academic achievement among African American adolescents. Adolescence, 42, 525-538.

Adelabu, D.H. (2008), Future time perspective, hope, and ethnic identity among African American adolescents. Urban Education, 43, 347-360.

Alwin D.F., Hofer S.M., McCammon R.J. (2011), Modeling the effects of time: Integrating demographic and developmental perspectives. W: R.H. Binstock, L.K. George (red.), Handbook of aging and the social sciences, 20-35. London, UK: Academic Press.

Arnett J.J. (2000), Emerging adulthood: A theory of development from the late teens through the twenties. American Psychologist, 55, 469-480.

Arnett J.J. (2007), Emerging adulthood: What is it, and what is it good for? Child Development Perspectives, $1,68-73$.

Bańka A. (2007), Globalizacja pracy i kariery a procesy identyfikacji społecznej i indywidualnej. W: M. Górnik-Durose, B. Kożusznik (red.), Perspektywy psychologii pracy, 53-81. Katowice: Wydawnictwo UŚ. 
Baron R.M, Kenny D.A. (1986), The moderator-mediator variable distinction in social research: Conceptual, strategic and statistical considerations. Journal of Personality and Social Psychology, 51, $1173-1182$.

Block R.A. (1990), Models of psychological time. W: R.A. Block (red.), Cognitive models of psychological time, 1-35. Hilldale, NJ: Erlbaum.

Boniwell I., Osin E., Linley P.A., Ivanchenko G.V. (2010), A question of balance: Time perspective and wellbeing in British and Russian sample. The Journal of Positive Psychology 2 5, 24-40.

Brandtstädter J. (2009), Goal pursuit and goal adjustment: Self-regulation and intentional self-development in changing developmental contexts. Advances in Life Course Research, 14, 52-62. DOI: 10.1016/j. alcr.2009.03.002.

Brzezińska A. (2000), Społeczna psychologia rozwoju. Warszawa: SCHOLAR.

Carstensen L.L. (2006), The influence of a sense of time on human development. Science, 312, 1913-1915.

Carstensen L.L., Isaacowitz D.M., Charles S.T. (1999), Taking time seriously. A theory of socioemotional selectivity. American Psychologist, 54, 165-181. DOI: 10.1037/0003-066X.54.3.165.

Chen T., Liu L.-L., Cui J.-F., Chen X.-J., Wang J., Zhang Y.-B., Chan R.C.K. (2016), Present-fatalistic time perspective and life satisfaction: The moderating role of age. Personality and Individual Differences, 99, 161-165. DOI: /10.1016/j.paid. 2016.05.017.

Chlewiński Z. (1977), Czas w aspekcie fizjologicznym i psychologicznym. Roczniki Filozoficzne, 25, 93-117.

Cierniak-Piotrowska M., Franecka A., Stańczak J., Stelmach K., Znajewska A. (2019) Sytuacja demograficzna Polski do 2018 r. Tworzenie i rozpad rodzin. Warszawa: Główny Urząd Statystyczny, Departament Badań Demograficznych.

Côté J.E. (2014), The dangerous myth of emerging adulthood: An evidence-based critique of a flawed developmental theory. Applied Developmental Science, 18, 177-188.

Cunningham K.F., Zhang J.W., Howell R.T. (2015), Time perspectives and subjective well-being: A dual-pathway framework. W: Stolarski M., Fieulaine N., Van Beek W. (red.) Time Perspective Theory; Review, Research and Application (s. 403-417). Cham: Springer.

De Volder M.L., Lens W. (1982), Academic achievement and Future Time Perspective as a cognitive- motivational concept. Journal of Personality and Social Psychology, 42, 566-571.

Desmyter F., De Raedt R. (2012), The relationship between time perspective and subjective well-being of older adults. Psychologica Belgica, 52, 19-38.

Drake L., Duncan E., Sutherland F., Abernathy C., Henry C. (2008), Time perspective and correlates of wellbeing. Time \& Society, 17, 47-61.

Erickson, E. H. (1968), Identity, youth, and crisis. New York: Norton Company.

Ferrari J.R., Diaz-Morales J.F. (2007), Procrastination: Different time orientations reflect different motives. Journal of Research in Personality, 41, 707-714.

Ferrari, J.R., \& Diaz-Morales, J.F. (2007), Procrastination: Different time orientations reflect different motives. Journal of Research in Personality, 41, 707-714.

Field A. (2013), Discovering statistics using IBM SPSS statistics (4. wyd.). Thousand Oaks, California: SAGE.

Fingerman K.L., Perlmutter M. (1995), Future time perspective and life events across adulthood. The Journal of General Psychology, 122, 95-111. DOI: 10.1080/00221309.195.9921225.

Fraisse P. (1963), Psychology of time. New York: Harper \& Row.

Galambos N.L., Barker E.T., Krahn H.J. (2006), Depression, self-esteem, and anger in emerging adulthood: Seven-year trajectories. Developmental Psychology, 42, 350-365.

Gao Y.J. (2011), Time Perspective and Life Satisfaction among Young Adults in Taiwan. Social Behaviour and Personality, 39, 729-736.

Gurba E. (2011), Wczesna dorosłość. W: J. Trempała (red.), Psychologia rozwoju człowieka. Podręcznik akademicki, 287-311. Warszawa: Wydawnictwo Naukowe PWN.

Hayes A.F. (2018), Introduction to mediation, moderation, and conditional process analysis. A regression-based approach. New York, London: The Guilford Press.

Heckhausen J., Schulz R. (1995), A life-span theory of control. Psychological Review, 102, 284-304. DOI: 10.1037/0033-295X.102.2.284. 
Hodgins D.C., Engel A. (2002), Future time perspective in pathological gamblers. The Journal of Nervous and Mental Disease, 190, 775-780.

Holman E.A., Silver R.C. (2005), Future-oriented thinking and adjustment in a nationwide longitudinal study following the September $11^{\text {th }}$ terrorist attacks. Motivation and Emotion, 29, 389-410. DOI: $10.1007 /$ s11031-006-9018-9.

Holman E.A., Silver R.C., Mogle J.A., Scott S.B. (2016), Adversity, time, and well being: A longitudinal analysis of time perspective in adulthood. Psychology of Aging, 31, 640-651.

Hoonaert J. (1973), Time perspective: Theoretical and methodological considerations. Psychologia Belgica, 13, 265-294.

Horn J.L. (1965), A rationale and test for the number of factors in factor analysis. Psychometrika, 30, 179-185. DOI: $10.1007 / \mathrm{BF} 02289447$.

Hulbert R.J., Lens W. (1988), Time and self- identity in later life. Aging and Human Development, 27, 293-303.

Isaacowitz D.M., Wadlinger H.A., Goren D., Wilson H.R. (2006), Is there an age-related positivity effect in visual attention? A comparison of two methodologies. Emotion, 6, 511-516. DOI:10.1037/1528-3542.6.3.511.

Juczyński Z. (2009), Narzędzia pomiaru w promocji i psychologii zdrowia. Warszawa: Pracownia Testów Psychologicznych PTP.

Lasane, T.P., O’Donnell, D.A. (2005), Time orientation measurement: A conceptual approach. W: A. Strathman, J. Joireman (red.), Understanding behavior in the context of time: Theory, research, \& application, 11-30. Hillsdale, NJ: Erlbaum.

Lasane, T.P., Jones, J.M. (2000), When socially induced temporal myopia interfers with academic goal-setting. Journal of Social Behavior and Personality, 15, 75-86.

Lennings C.L., Burns A.M., Cooney G. (1998), The profiles of time perspective and personality: Developmental considerations. Journal of Psychology, 132, 629-641.

Lens W. (2004), Future Time Perspective. A psychological approach. Paper presented at the Symposium: The Psychology of time: Theoretical Inspirations, Experience, Temporal Competencies, Empirical Approaches. Lublin: Catholic University of Lublin.

Lens W., Moreas M.A. (1994), Future time perspective: An individual and a societal approach. W: Z. Zaleski (red.), Psychology of future orientation, 23-38. Lublin: Towarzystwo Naukowe KUL.

Liberska, H. (2004), Perspektywy temporalne młodzieży. Wybrane uwarunkowania. Poznań: Wydawnictwo Naukowe UAM.

Łukaszewski W. (1983), Orientacja temporalna jako jeden z aspektow osobowości. W: W. Łukaszewski (red.), Osobowość - orientacja temporalna-ustosunkowanie do zmian, 5-39. Wrocław: Wydawnictwo Uniwersytetu Wrocławskiego.

Łukaszewski W. (1984), Umiejscowienie w czasie. W: W. Łukaszewski, Szanse rozwoju osobowości, 157-184. Warszawa: Wydawnictwo Książka i Wiedza.

MacMillan R. (2007), Constructing adulthood: Agency and subjectivity in adolescence and adulthood. Advances in Life Course Research, 11, 3-29.

Molinari L., Speltini G., Passini S., Carelli M.G. (2016), Time perspective in adolescents and young adults: Enjoying the presence and trusting in a better future. Time \& Society, 25, 594-612. DOI: 10.1177/0961463X15587833.

Murphy, K.A., Blustein, D.L., Bohlig, A.J., Platt, M.G. (2010), The college-to-career transition: An exploration of emerging adulthood. Journal of Counseling \& Development, 88, 174-181.

Nawrat, R. (1981), Orientacja temporalna. Przegląd technik pomiaru i wyników badań. Przeglą Psychologiczny, 24, 97-123.

Nosal, Cz., Bajcar, B. (2004), Czas psychologiczny: wymiary, struktura, konsekwencje. Warszawa: Wydawnictwo Instytutu Psychologii PAN.

Nurmi, J.-E. (1991), How do adolescents see their future? A review of the development of future orientation and planning. Developmental Review, 11, 1-59.

Nuttin J. (1985), Future time perspective and motivation. Theory and research method. Leuven: Leuven University Press.

Obuchowski K. (1987), Psychologiczne aspekty orientacji temporalnej. W: K. Cackowski, J. Wojczakowski (red.), Stosunek do czasu w różnych strukturach kulturowych, 43-51. Warszawa: ANS. 
Oleszkowicz, A., Misztela, A. (2015), Kryteria dorosłości z perspektywy starszych adolescentów i młodych dorosłych. Psychologia Rozwojowa, 20, 41-55. DOI: 10.4467/20843879PR.15.002.3474.

Ornstein R.W. (1969), On the experience of time. New York: American Elsevier.

Pawluczuk W. (1987), Czas w różnych systemach aktywności człowieka. W: K. Cackowski, J. Wojczakowski (red.), Stosunek do czasu w różnych strukturach kulturowych, 29-42. Warszawa: ANS.

Phan H.P. (2009), Amalgamation of future time orientation, epistemological beliefs, achievement goals and study strategies: Empirical evidence established. British Journal of Educational Psychology, 79, 155-173.

Przepiórka, A., Sobol-Kwapinska, M. (2018), Religiosity moderates the relationship between time perspective and life satisfaction. Personality and Individual Differences, 134, 261-267. DOI: 10.1016/j.paid.2018.05.039.

Reinherz H.Z., Paradis A.D., Giaconia R.M., Stashwick C.K., Fitzmaurice G. (2003), Childhood and adolescent predictors of major depressive disorder in the transition to adulthood. American Journal of Psychiatry, 160, 2141-2147.

Rękosiewicz M. (2014), Orientacja życiowa i typ partycypacji społecznej w okresie adolescencji i wyłaniającej się dorosłości. Kontekst edukacyjny. Psychologia Rozwojowa, 19, 73-85.

Schwartz S.J. (2016), Turning point for a turning point: Advancing emerging adulthood theory and research. Emerging Adulthood, 4, 307-317. DOI: 10.1177/2167696815624640.

Settersten R. (2011), Becoming adult: Meaning and makers for young Americans. W: M.C. Waters, P.J. Carr, M.J. Kefals, J. Holdaway (red.). Coming of age in America: The transition to adulthood in twenty-first century, 169-190. Berkley: University of California Press.

Shipp, A.J., Edwards, J.R., Schurer-Lambert, L. (2009), Conceptualization and measurement of temporal focus: The subjective experience of the past, present, and future. Organizational Behavior and Human Decision Processes, 110, 1-22. DOI: 10.1016/j.obhdp.2009.05.001.

Simons J., Dewitte S., Lens W. (2004), The role of different types of instrumentality in motivation, study strategies, and performance: Know why you learn, so you'll know what you learn! British Journal of Educational Psychology, 74, 343-360.

Stevens J.P. (1992), Applied multivariate statistics for the social sciences $\left(2^{\text {nd }}\right.$ ed.). Hillsdale. NJ: Erlbaum.

Stolarski, M., Bitner, J., Zimbardo, P.G. (2011), Time perspective, emotional intelligence and discounting of delayed awards. Time \& Society, 20, 346-363.

Suddendorf T., Corballis M.C. (1997), Mental time travel and the evolution of the human mind. Genetic, Social, and General Psychology Monographs, 123, 133-167.

Tabachnick B.G., Fidel L.S. (2007), Using Multivariate Statistics. Boston: Pearson Education. Inc.

Temple E.C. (2013), Associations between psychological well-being and development of beneficial time perspectives. Annales Universitatis Paedagogicae Cracoviensis. Studia Psychologica, 6, 72-87.

Tucholska K. (2007), Kompetencje temporalne jako wyznacznik dobrego funkcjonowania. Lublin: Towarzystwo Naukowe KUL.

Van Beek, W., Kerkhof, A., Beekman, A. (2011), Time perspective, personality and psychopathology: Zimbardo's Time Perspective Inventory in psychiatry. Time \& Society, 20, 364-374.

Watkins M.W. (2000), Monte Carlo PCA for Parallel Analysis. State College, PA: Ed \& Psych Associates.

Wiszejko-Wierzbicka D., Kwiatkowska A. (2018), Wchodzenie Polaków w dorosłość. Ogólnopolskie badanie młodych Polaków w wieku 18-29 lat. Studia Socjologiczne, 229, 147-176.

Worrell, F. C., Temple, E. C., McKay, M. T., Živkovič, U., Perry, J. L. Mello, Z. R., Musil, B., Cole, J.C. (2018), A Theoretical Approach to Resolving the Psychometric Problems Associated With the Zimbardo Time Perspective Inventory. Results From the USA, Australia, Slovenia, and the United Kingdom. European Journal of Psychological Assessment, 34, 41-51. DOI: 10.1027/1015-5759/a000313.

Zagórska W. (2004), Uczestnictwo młodych dorostych w rzeczywistości wykreowanej kulturowo. Kraków: Universitas.

Zaleski Z. (1988), Transtemporalne „ja”: osobowość w trzech wymiarach czasowych. Przeglad Psychologiczny, 31, 931-945.

Zaleski Z. (1991), Psychologia zachowań celowych. Warszawa: Wydawnictwo Naukowe PWN.

Zhang J.W., Howell R.T., Stolarski M. (2013), Comparing three methods to measure a balanced time perspective: The relationship between a balanced time perspective and subjective well-being. Journal of Happiness Studies, 14, 169-184. DOI: 10.1007/s10902-012-9322-x. 
Zimbardo P.G. (2002), Time to take our time. Psychology Today, 35, 62.

Zimbardo P.G., Boniwell I. (2007), Zrównoważona perspektywa czasowa jako warunek optymalnego funkcjonowania. W: A. Linley, S. Joseph (red.), Psychologia pozytywna w praktyce, 112-131. Warszawa: Wydawnictwo Naukowe PWN.

Zimbardo P.G., Boyd J.N. (1999), Putting time in perspective: A valid, reliable individual differences metric. Journal of Personality and Social Psychology, 77, 1271-1288.

Zimbardo P.G., Boyd J.N. (2009), Paradoks czasu. Warszawa: Wydawnictwo Naukowe PWN.

Zimbardo P.G., Gonzalez A. (1985), Time in perspective. Psychology Today, 3, 21-26.

Zimbardo P.G., Sword R.M., Sword R.K.M. (2012), Time cure: Overcoming PTSD with the new psychology of time perspective therapy. San Francisco, CA: Jossey-Bass. 